\title{
The form of folate affects the mechanisms of methotrexate resistance in Enterococcus faecium
}

\author{
Tsunenobu Tamura, ${ }^{1}$ Joseph E. Baggott, ${ }^{1}$ Kelley E. Johnston, ${ }^{1}$ \\ Qing-Jun Li' and Asok C. Antony ${ }^{2}$ \\ Author for correspondence: Tsunenobu Tamura. Tel: +1 2059347478. Fax: +1 2059347049. \\ e-mail: tamurat@uab.edu
}

1 Department of Nutrition Sciences, University of Alabama at Birmingham, Birmingham, AL 35294, USA

2 Department of Medicine, Indiana University School of Medicine, Indianapolis, IN 46202, USA

\begin{abstract}
Several mechanisms have been described to explain the resistance of cells to methotrexate (MTX); however, the basis for the heterogeneity of mechanisms has been obscure. It was hypothesized that the type of MTX resistance in a single species can be influenced by the form of extracellular folate supplied during the development of resistance. Two strains of MTX-resistant Enterococcus faecium were developed by transferring the bacteria to media containing increasing concentrations of MTX in the presence of constant concentrations of either 5-formyl-5,6,7,8-tetrahydropteroylglutamic acid (5HCO-H ${ }_{4}$ PteGlu) or pteroylglutamic acid (PteGlu). These resistant strains were designated E. faecium/MTX/5-HCO-H PteGlu and E. faecium/MTX/PteGlu, respectively. The mechanisms of MTX resistance included: (1) increased folic acid reductase (FAR) activity in both resistant strains but increased dihydrofolate reductase (DHFR) activity only in E. faecium/MTX/PteGlu; (2) decreased synthesis and intracellular retention of MTX containing two glutamyl residues; (3) decreased uptake of MTX accompanied by decreased uptake of folates; and (4) reduction of folate-binding capacity. Among these, the form of folate present in the media during the development of resistance affected DHFR and FAR activities and the transport of folates. These findings, together with data from other laboratories, suggest that it may be important to use a reduced form of folate, a more physiological form than oxidized PteGlu, in the media during the development of resistance for the study of the mechanisms of MTX resistance in cultured cells.
\end{abstract}

Keywords: methotrexate resistance, Enterococcus faecium, folate, dihydrofolate reductase, folate-binding protein

\section{INTRODUCTION}

Methotrexate (MTX), an antifolate, has been widely used for cancer treatment since its development and the identification of its biological activities (Franklin et al., 1949). MTX is a classical type of inhibitor of dihydrofolate reductase (DHFR, 5,6,7,8-tetrahydrofolate$\mathrm{NADP}^{+}$oxidoreductase, EC 1.5.1.3; reactions 1 and 2, Fig. 1) (Blakley, 1984; Schweitzer et al., 1990) and is

Abbreviations: DHFR, dihydrofolate reductase; FAR, folic acid reductase; FBP, folate-binding protein; MTX, methotrexate; PteGlu, pteroylglutamic acid; $\mathrm{H}_{2}$ PteGlu, dihydrofolate; $\mathrm{H}_{4}$ PteGlu, tetrahydrofolate; 5-HCO$\mathrm{H}_{4}$ PteGlu, 5-formyl-5,6,7,8-tetrahydropteroylglutamic acid. known to be metabolized to polyglutamyl forms after its incorporation into cells (Whitehead et al., 1975). The development of resistance to MTX is one of the most serious problems in cancer chemotherapy. Many researchers have proposed possible mechanisms for the development of MTX resistance including one or a combination of the following mechanisms: (1) gene amplification of DHFR (Alt et al., 1976; Haber et al., 1981); (2) mutation to produce DHFR with decreased affinity to MTX (Haber et al., 1981); (3) decreased activity of folylpolyglutamate synthetase (EC 6.3.2.17; reaction 3, Fig. 1) leading to reduced MTX polyglutamate synthesis (Jolivet et al., 1982); (4) increased activity of folate conjugase (pteroyl-poly- $\gamma$-glutamyl carboxypeptidase, EC 3.4.19.9; reaction 4, Fig. 1) to 


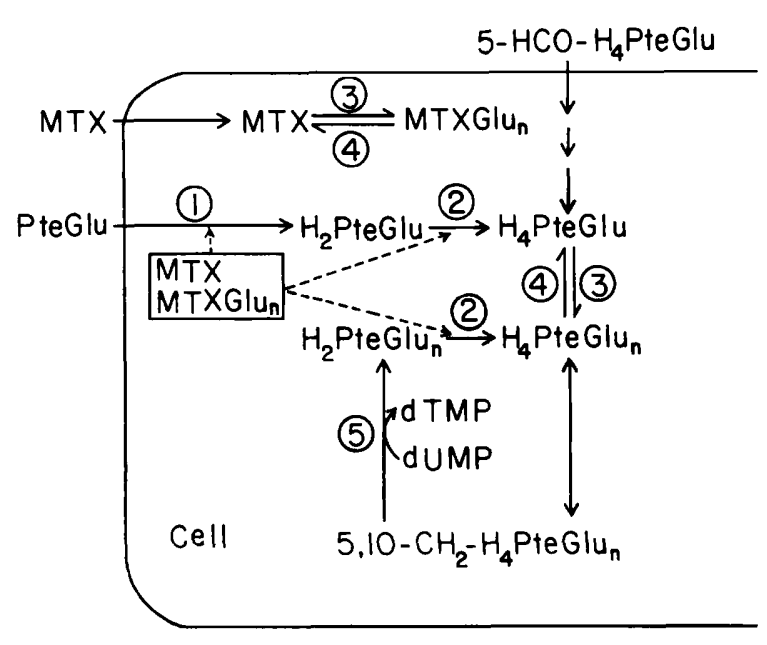

Fig. 1. Effect of MTX on folate metabolism. 1, FAR; 2, DHFR; 3 , folylpolyglutamate synthetase; 4 , folate conjugase; 5 , thymidylate synthase. The broken lines indicate inhibition by MTX and MTXGlu

reduce the glutamyl chain-length of MTX (Prescot \& Affronti, 1968; Sur et al., 1986); (5) increased synthesis of pteroylpolyglutamates for the maintenance of intracellular folate homeostasis (Roy et al., 1995); (6) decreased transport of MTX into cells via either the low-affinity high-capacity reduced-folate carrier or by a reduction in expression of folate receptor (Antony, 1996); and (7) increased expression of the protein associated with multidrug resistance (Shen et al., 1986).

Enterococcus (formerly Streptococcus) faecium ATCC 8043 is routinely used in the microbiological assay of folates (Tamura, 1990). Wild-type E. faecium does not survive in the presence of MTX, since dihydrofolate $\left(\mathrm{H}_{2}\right.$ PteGlu), a product of thymidylate synthase (EC 2.1.1.45; reaction 5, Fig. 1 ), cannot be recycled to tetrahydrofolate $\left(\mathrm{H}_{4}\right.$ PteGlu) due to the inhibition of DHFR. To determine folate concentrations in plasma containing MTX, Hutchison (1957) developed a strain of MTX-resistant E. faecium. Since then, the characterization of DHFR in MTX-resistant strains of $E$. faecium has been carried out by many investigators (Blakley, 1984). However, the mechanisms by which resistance to MTX develops in E. faecium have not yet been extensively studied and the effect of the form of folate on the development of MTX resistance has, to our knowledge, never been explored. We undertook this study to identify the mechanisms of MTX resistance in E. faecium and the effect of folate derivatives on its development.

\section{METHODS}

Strains and chemicals. Wild-type E. faecium (E.faecium/wild) was obtained from the American Type Culture Collection (Rockville, MD, USA) and folic acid assay medium from Difco. MTX, pteroylglutamic acid (PteGlu) and $[6 R, S]-5$ - formyltetrahydropteroyl glutamic acid $\left(5-\mathrm{HCO}-\mathrm{H}_{4} \mathrm{PteGlu}\right)$ were purchased from Sigma. $\left[3^{\prime}, 5^{\prime}, 7,9-{ }^{3} \mathrm{H}\right] 5-\mathrm{HCO}-\mathrm{H}_{4}$ PteGlu $\left(94 \times 10^{10} \mathrm{~Bq} \mathrm{mmol}^{-1}\right),\left[3^{\prime}, 5^{\prime}, 7,9-{ }^{3} \mathrm{H}\right]$ PteGlu $\left(100 \times 10^{10} \mathrm{~Bq}\right.$ $\left.\mathrm{mmol}^{-1}\right)$ and $\left[3^{\prime}, 5^{\prime}, 7{ }^{3} \mathrm{H}\right] \mathrm{MTX}\left(71 \times 10^{10} \mathrm{~Bq} \mathrm{mmol}^{-1}\right)$ were obtained from Moravek. $\mathrm{H}_{2}$ PteGlu was prepared according to the method described by Futterman (1963). MTX containing a total of four glutamyl residues (MTXGlu ${ }_{3}$ ) and pteroyltriglutamate with the end glutamate labelled with ${ }^{14} \mathrm{C}$ (PteGlu ${ }_{2}\left[{ }^{14} \mathrm{C}\right] \mathrm{Glu}$ ) were synthesized by the solid-phase technique of Krumdieck \& Baugh (1969). Chicken pancreas folate conjugase was partially purified as described by Leichter $e t a l$. (1977).

Two strains of MTX-resistant E. faecium were developed by transferring bacteria to successively greater concentrations of MTX. The strain in which MTX resistance was developed in the presence of PteGlu was designated $E$. faecium/MTX/PteGlu and that developed in the presence of 5 - $\mathrm{HCO}-\mathrm{H}_{4}$ PteGlu as E. faecium $/ \mathrm{MTX} / 5-\mathrm{HCO}-\mathrm{H}_{4}$ PteGlu. The initial concentrations of MTX for the development of MTX resistance were $200 \mathrm{pM}$ and $2.0 \mathrm{pM}$ for $E$. faecium/MTX/PteGlu and E. faecium/MTX/5-HCO$\mathrm{H}_{4}$ PteGlu, respectively. The concentrations of 5 - $\mathrm{HCO}$ $\mathrm{H}_{4}$ PteGlu $(5.4 \mathrm{nM})$ or PteGlu $(11.3 \mathrm{nM})$ were kept constant during the development of MTX resistance. The response curves of these strains to either PteGlu or $5-\mathrm{HCO}-\mathrm{H}_{4}$ PteGlu with various concentrations of MTX were constructed using 96-well microplates and a plate reader (Model 2550, Bio-Rad) (Tamura, 1990).

Enzyme assays. For the determinations of activities of DHFR, folic acid reductase (FAR) and folate conjugase, $E$. faecium/MTX/PteGlu was incubated in approximately $1 \cdot 0$ litres of medium containing PteGlu (11.3 nM), and E. faecium /MTX/5-HCO- $\mathrm{H}_{4}$ PteGlu and E. faecium/wild in medium containing $5-\mathrm{HCO}-\mathrm{H}_{4}$ PteGlu $(11.3 \mathrm{nM})$ without MTX for $16 \mathrm{~h}$ at $37^{\circ} \mathrm{C}$. The bacteria were independently harvested by centrifugation at $6000 \mathrm{~g}$ for $20 \mathrm{~min}$ at $4{ }^{\circ} \mathrm{C}$, and washed twice with $50 \mathrm{ml} 0.05 \mathrm{M}$ potassium phosphate buffer $(\mathrm{pH} 6.5)$. They were suspended in $20 \mathrm{ml}$ of the same buffer and the cell membranes disrupted using a French press followed by centrifugation at $12000 \mathrm{~g}$ for $20 \mathrm{~min}$ at $6^{\circ} \mathrm{C}$. The supernatant of each strain was kept at $-70^{\circ} \mathrm{C}$ and used as an enzyme source.

The activities of DHFR were measured in triplicate by the method described by Nixon \& Blakley (1968) using $\mathrm{H}_{2}$ PteGlu as substrate. The reaction mixture contained $38 \mu \mathrm{M} \mathrm{H}_{2} \mathrm{PteGlu}$, $50 \mu \mathrm{M}$ NADPH, $10 \mu \mathrm{M}$ mercaptoethanol and $30 \mathrm{mM}$ potassium phosphate buffer ( $\mathrm{pH} \mathrm{6.7)}$, and the enzyme preparation in a total of $1.0 \mathrm{ml}$. The decrease in absorbance at $340 \mathrm{~nm}$ was monitored using a spectrophotometer with temperature control $\left(37^{\circ} \mathrm{C}\right)$ and a control module allowing absorbance to be recorded at $30 \mathrm{~s}$ intervals (Spectronic 601, Milton Roy). The molar absorption coefficient of $12300 \mathrm{M}^{-1} \mathrm{~cm}^{-1}$ for the reaction at $340 \mathrm{~nm}$ was used to calculate the enzyme activity (Nixon \& Blakley, 1968). The activities of FAR were determined in triplicate using $\left[{ }^{3} \mathrm{H}\right]$ PteGlu as substrate (Rothenberg, 1965). The standard incubation mixture consisted of $0.2 \mathrm{mM}\left[{ }^{3} \mathrm{H}\right]$ PteGlu, $1.0 \mathrm{mM}$ NADPH, $100 \mathrm{mM}$

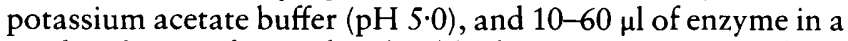
total volume of $200 \mu \mathrm{l}$. The blank mixture contained no enzyme and the counts of the blank were subtracted for calculation of the enzyme activity. After incubation at $37^{\circ} \mathrm{C}$ for $20 \mathrm{~min}, 40 \mu \mathrm{l} 27 \mathrm{mM}$ PteGlu, $10 \mu \mathrm{l}$ glacial acetic acid and $40 \mu \mathrm{l} 0.17 \mathrm{M}$ zinc sulfate were added to the mixture, kept in ice water for $10 \mathrm{~min}$ and then centrifuged at $3000 \mathrm{~g}$ for $10 \mathrm{~min}$ at $4^{\circ} \mathrm{C}$. The supernatant $(145 \mu \mathrm{l})$ was mixed with $2.0 \mathrm{ml}$ counting fluid (Gold Ultima, Packard Instrument) and the radioactivity 
measured using a scintillation counter (Model 1219 Rackbeta, LKB). Folate conjugase activity was measured in triplicate by the method of Krumdieck \& Baugh (1970) using PteGlu ${ }_{2}\left[{ }^{14} \mathrm{C}\right] \mathrm{Glu}$ as substrate. The incubation was carried out up to a maximum of $6 \mathrm{~h}$ at $37^{\circ} \mathrm{C}$. Protein concentrations were measured using a Bio-Rad Protein Assay kit.

Metabolism of MTX. This was determined using cell extracts after MTX-resistant and wild-type E. faecium were individually incubated in the regular assay media containing $3.7 \times 10^{4} \mathrm{~Bq}(0.05 \mathrm{nmol})\left[{ }^{3} \mathrm{H}\right] \mathrm{MTX}\left(71 \times 10^{10} \mathrm{~Bq} \mathrm{mmol}{ }^{-1}\right)$ and $11.0 \mathrm{nM}$ folates for $18 \mathrm{~h}$ and washed using saline. The bacteria were disrupted in a French pressure cell, heated in boiling water for $10 \mathrm{~min}$ and centrifuged at $900 \mathrm{~g}$ for $5 \mathrm{~min}$. The supernatants $(1.0 \mathrm{ml}$ each) were applied to a Sephadex G-25 column $(1 \times 120 \mathrm{~cm})$ and eluted with $0 \cdot 1 \mathrm{M}$ potassium phosphate buffer (pH 6.0) (Shin et al., 1974). Fractions $(3.0 \mathrm{ml})$ were collected and the radioactivity measured. Extracellular fluids were also applied to a Sephadex G-25 column without

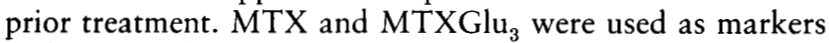
and their elution was monitored by determining UV absorbance at $303 \mathrm{~nm}$ (Blakley, 1969).

Uptake of folates. The uptake of $\left[{ }^{3} \mathrm{H}\right] 5-\mathrm{HCO}-\mathrm{H}_{4}$ PteGlu and $\left[{ }^{3} \mathrm{H}\right]$ PteGlu by the three strains of E. faecium was determined with and without MTX. E. faecium were harvested by centrifugation $\left(1800 \mathrm{~g}\right.$ for $15 \mathrm{~min}$ at $8{ }^{\circ} \mathrm{C}$ ) after an $18 \mathrm{~h}$ incubation at $37^{\circ} \mathrm{C}$ in $10.0 \mathrm{ml}$ of media without MTX. The bacteria were washed twice with $0 \cdot 14 \mathrm{M} \mathrm{NaCl}$ and suspended in $10.0 \mathrm{ml} 0.1 \mathrm{M}$ potassium phosphate buffer $(\mathrm{pH} 6.3$ ) containing $56 \mathrm{mM}$ glucose. The optical density of the bacterial suspension was measured at $600 \mathrm{~nm}$ using a microplate reader. This suspension $(20 \mu \mathrm{l})$ was incubated in a total volume of $5.0 \mathrm{ml}$ potassium phosphate buffer containing glucose as above at $37^{\circ} \mathrm{C}$ for $2 \mathrm{~min}$ prior to the addition of $0.20 \times 10^{10} \mathrm{~Bq}$ of either $\left[{ }^{3} \mathrm{H}\right] 5-\mathrm{HCO}-\mathrm{H}_{4}$ PteGlu $\left(94 \times 10^{10} \mathrm{~Bq} \mathrm{mmol}{ }^{-1}\right)$ or $\left[{ }^{3} \mathrm{H}\right]$ PteGlu $\left(100 \times 10^{10} \mathrm{~Bq} \mathrm{mmol}^{-1}\right)$. Aliquots $(1.0 \mathrm{ml})$ were removed at various intervals $(1-15 \mathrm{~min})$ and filtered using a $0.22 \mu \mathrm{m}$ microfilter (Millipore). After the bacteria on the microfilter had been washed three times with $1.0 \mathrm{ml}$ ice-cold water, the filter was placed in counting fluid and the radioactivity measured. The uptake experiments were repeated three times and the means are presented. The term 'uptake' was defined as the amount of radioactivity found in the cells after washing and expressed as pmol per $10 \mathrm{~min}$ per $\mathrm{OD}_{600}$ unit. The uptake of $\left[{ }^{3} \mathrm{H}\right] \mathrm{MTX}$ was determined in a similar manner.

Folate-binding protein (FBP) assay. The determination of $\left[{ }^{3} \mathrm{H}\right]$ PteGlu-bound folate-binding protein was carried out using bacteria harvested by centrifuging $(4000 \mathrm{~g}$ for $20 \mathrm{~min}$ at $\left.8^{\circ} \mathrm{C}\right) 1.1$ litres of media containing each strain of E. faecium incubated for $18-24 \mathrm{~h}$ with $2 \cdot 27 \mathrm{nM}$ of either 5-HCO$\mathrm{H}_{4}$ PteGlu or PteGlu without MTX. Cells were disrupted in a French pressure cell with $5.0 \mathrm{ml} 0.1 \mathrm{M}$ potassium phosphate buffer $(\mathrm{pH} 7 \cdot 5)$. Each cell extract was mixed with an equal volume of buffer containing $4 \%(\mathrm{w} / \mathrm{v})$ Triton X-100 and $0.1 \%(\mathrm{w} / \mathrm{v})$ sodium azide. The mixtures were shipped from Birmingham to Indianapolis on wet ice. The mixtures were solubilized by shaking for $24 \mathrm{~h}$ at $4{ }^{\circ} \mathrm{C}$. To dissociate endogenous folates bound to FBP, the mixtures were dialysed against 4.0 litres $50 \mathrm{mM}$ sodium acetate $(\mathrm{pH} 4.5)$ for $3 \mathrm{~d}$, followed by a second 3-d-dialysis against $3 \cdot 0$ litres $100 \mathrm{mM}$ potassium phosphate buffer $(\mathrm{pH} 7.5)$ and a third dialysis against $4 \cdot 0$ litres $10 \mathrm{mM}$ potassium phosphate buffer $(\mathrm{pH} 7 \cdot 5)$. All dialysates contained $1 \%$ Triton X-100 and $0.05 \%$ sodium azide, and were changed every $12 \mathrm{~h}$ throughout dialysis. All dialysis procedures were carried out at $4{ }^{\circ} \mathrm{C}$. The dialysed samples were centrifuged at $13600 \mathrm{~g}$ for $15 \mathrm{~min}$, and the concentrations of protein were measured in each supernatant (Smith et al., 1985). Aliquots of each supernatant were incubated with $123 \mathrm{pmol}\left[{ }^{3} \mathrm{H}\right]$ PteGlu for $45 \mathrm{~min}$ at $37^{\circ} \mathrm{C}$ and applied to a calibrated Sephacryl S-200 column $(2.5 \times 30.0 \mathrm{~cm}$, Spectrum Medical Industries), which was eluted with $10 \mathrm{mM}$ potassium phosphate buffer ( $\mathrm{pH} 7.5)$ containing $1 \%$ Triton $\mathrm{X}-100$ and $0.05 \%$ sodium azide at $4{ }^{\circ} \mathrm{C}$ (Verma \& Antony, 1991). Fractions $(2.75 \mathrm{ml})$ were collected and their radioactivity measured. The entire procedure was repeated and the data presented are the means of two experiments. For both Sephadex G-25 and Sephacryl S-200 columns, the void volume $\left(V_{0}\right)$ was determined with blue dextran with a molecular mass of $2000 \mathrm{kDa}$.

\section{RESULTS}

\section{MTX-resistant strains}

As shown in Fig. 2, wild-type E. faecium were made resistant to a final concentration of $40 \mu \mathrm{M}$ MTX by transferring bacteria daily in increasing concentrations of MTX with a constant concentration of 5-HCO$\mathrm{H}_{4}$ PteGlu or PteGlu. It required 19 transfers to develop resistance to a final concentration of $40 \mu \mathrm{M}$ MTX for $E$. faecium/MTX/5-HCO- $\mathrm{H}_{4}$ PteGlu, whereas only six transfers were required for E. faecium/MTX/PteGlu. The growth responses of these mutant strains and $E$. faecium/wild to 5-HCO- $\mathrm{H}_{4}$ PteGlu and PteGlu with varying concentrations of MTX $(0-25 \mu \mathrm{M})$ are illustrated in Fig. 3(a-c). Although both MTX-resistant strains maintained their ability to respond to 5-HCO$\mathrm{H}_{4}$ PteGlu, E. faecium/MTX/5-HCO- $\mathrm{H}_{4}$ PteGlu did not show any response to PteGlu in the presence of $25 \mu \mathrm{M}$ MTX, and the ability of this strain to respond to PteGlu was substantially reduced even in the absence of MTX

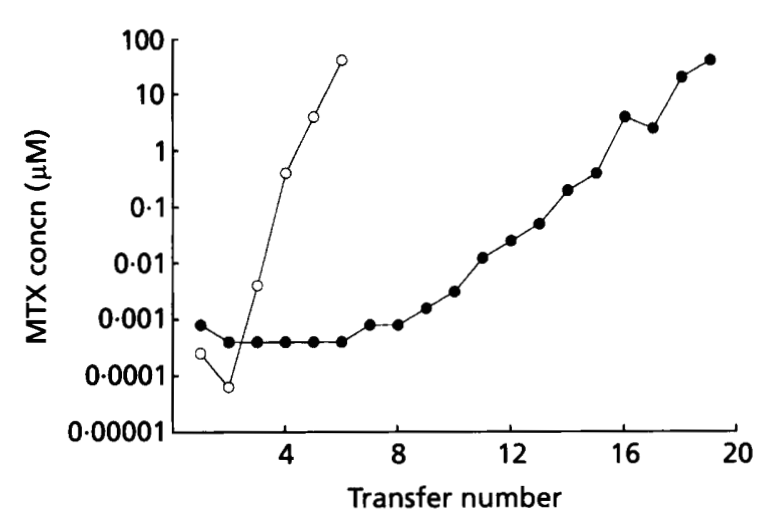

Fig. 2. Development of MTX-resistant $E$. faecium. Wild-type $E$. faecium was initially grown in medium containing 200 pM MTX and $11.3 \mathrm{nM}$ PteGlu $(O)$ or in medium containing $2 \mathrm{pM}$ MTX and $5.4 \mathrm{nM} 5-\mathrm{HCO}-\mathrm{H}_{4}$ PteGlu (O). Bacteria which showed sufficient growth $\left(O D_{600}\right.$ of 0.4$)$ were transferred daily to media containing higher concentrations of MTX. The $O_{600}$ of this transferred bacterial suspension was almost equal to that of the blank (approximately 0.1 ) since only $0.15 \mu \mathrm{l}$ of the original bacterial suspension of the previous day was mixed with $300 \mu \mathrm{l}$ medium. The vertical scale indicates the concentrations of MTX to which $E$. faecium developed resistance. 

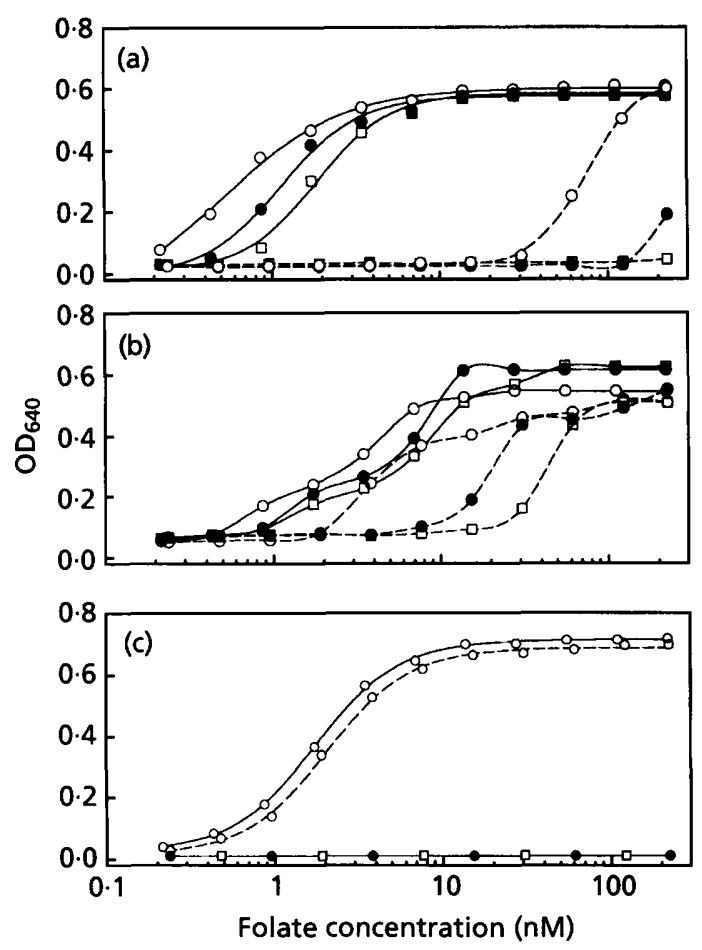

Fig. 3. Growth responses of MTX-resistant $(a, b)$ and wild-type (c) E. faecium to $5-\mathrm{HCO}-\mathrm{H}_{4}$ PteGlu $(-)$ and PteGlu $(--)$ with $10 \mu \mathrm{M}$ (O) or $25 \mu \mathrm{M}(\square) \mathrm{MTX}$ or without MTX (O). (a) E. faecium/MTX/5-HCO-H ${ }_{4}$ PteGlu; (b) E. faecium/MTX/PteGlu; (c) E. faecium/wild.
(Fig. 3a). Furthermore, for this mutant strain, the concentration of PteGlu which gave half-maximum growth was $80 \mathrm{nM}$ without MTX, which was significantly higher than that for E. faecium/wild $(2.5 \mathrm{nM})$ and E. faecium/MTX/PteGlu (4.0 nM) (Table 1). E. faecium/MTX/PteGlu retained the ability to respond to PteGlu (Fig. 3b). As expected, MTX-sensitive E. faecium/wild did not respond to either 5-HCO$\mathrm{H}_{4}$ PteGlu or PteGlu in the presence of MTX (Fig. 3c).

\section{Enzyme activities}

As shown in Table 1, the activities of DHFR and FAR and the uptakes of $\left[{ }^{3} \mathrm{H}\right]$ folates were affected by the form of folate in the media during the development of resistance. E. faecium/MTX/PteGlu had markedly increased activities of DHFR and FAR as compared to E. faecium/wild, whereas FAR activity in $E$. faecium/MTX/5-HCO- $\mathrm{H}_{4} \mathrm{PteGlu}$ was three times higher than that in E. faecium/wild. Folate conjugase activity was not detected in any strain of E. faecium under the assay conditions employed in this study.

\section{Metabolism of MTX}

The Sephadex G-25 chromatograms of intracellular and extracellular derivatives of $\left[{ }^{3} \mathrm{H}\right]$ MTX in MTX-resistant and wild-type E. faecium are shown in Fig. $4(\mathrm{a}, \mathrm{b})$. The chromatographic data indicate that approximately $81 \%$ of $\left[{ }^{3} \mathrm{H}\right] \mathrm{MTX}$ incorporated into $E$. faecium/wild was

Table 1. Mechanisms of MTX resistance in E. faecium

\begin{tabular}{|c|c|c|c|}
\hline & $\begin{array}{l}\text { E. faecium/ } \\
\text { MTX/5-HCO- }{ }_{4} \text { PteGlu }\end{array}$ & $\begin{array}{l}\text { E. faecium/ } \\
\text { MTX/PteGlu }\end{array}$ & $\begin{array}{l}\text { E. faecium/ } \\
\text { wild }\end{array}$ \\
\hline $\begin{array}{l}\text { PteGlu concentration for half-maximum growth } \\
\text { (nM) }\end{array}$ & 80 & $4 \cdot 0$ & $2 \cdot 5$ \\
\hline $\begin{array}{l}\text { DHFR activity [nmol } \mathrm{H}_{4} \text { PteGlu formed (mg } \\
\left.\text { protein) })^{-1}\right]^{*}\end{array}$ & $52 \pm 13$ & $589 \pm 170$ & $63 \pm 24$ \\
\hline $\begin{array}{l}\text { FAR activity [pmol } \mathrm{H}_{4} \text { PteGlu formed (mg } \\
\left.\text { protein) })^{-1}\right]^{*}\end{array}$ & $9 \cdot 0 \pm 2 \cdot 4$ & $33 \cdot 0 \pm 9 \cdot 9$ & $3 \cdot 0 \pm 1 \cdot 6$ \\
\hline Folate conjugase activity $\left(\mathrm{pmol} \mathrm{mg}^{-1} \mathrm{~h}^{-1}\right)^{*}$ & $<12$ & $<12$ & $<12$ \\
\hline $\begin{array}{l}\text { MTXGlu synthesis (\% of intracellular counts found } \\
\text { as MTXGlu) }\end{array}$ & 5 & 8 & 81 \\
\hline $\begin{array}{l}\text { MTXGlu retention (\% of MTXGlu counts found } \\
\text { intracellularly) }\end{array}$ & 0 & 0 & 78 \\
\hline $\begin{array}{l}{\left[{ }^{3} \mathrm{H}\right] 5-\mathrm{HCO}-\mathrm{H}_{4} \text { PteGlu uptake }(\% \text { of uptake by } E \text {. }} \\
\text { faecium } / \text { wild })^{*} \dagger\end{array}$ & $25 \pm 7$ & $46 \pm 8$ & 100 \\
\hline $\begin{array}{l}{\left[{ }^{3} \mathrm{H}\right] \text { PteGlu uptake }(\% \text { of uptake by } E \text {. }} \\
\text { faecium } / \text { wild })^{*} \dagger\end{array}$ & $10 \pm 3$ & $16 \pm 7$ & 100 \\
\hline $\begin{array}{l}{\left[{ }^{3} \mathrm{H}\right] \mathrm{MTX} \text { uptake }(\% \text { of uptake by } E \text {. }} \\
\text { faecium } / \text { wild })^{*} \dagger\end{array}$ & $27 \pm 9$ & $21 \pm 6$ & 100 \\
\hline$\left[{ }^{3} \mathrm{H}\right]$ PteGlu-bound FBP $\left[\mathrm{pmol}(\mathrm{mg} \text { protein })^{-1}\right]$ & 0.63 & $0 \cdot 27$ & 6.7 \\
\hline
\end{tabular}

*Data are means of two or three experiments.

†Uptake by E. faecium/wild ( $\pm \mathrm{SD}$ ) was $2 \cdot 0( \pm 0.3)$ pmol per $10 \mathrm{~min}$ per $\mathrm{OD}_{600}$ unit for $\left[{ }^{3} \mathrm{H}\right] 5-\mathrm{HCO}-\mathrm{H}_{4} \mathrm{PteGlu}, 4 \cdot 0$ ( $\left.\pm 0 \cdot 9\right)$ pmol per 10 min per $\mathrm{OD}_{600}$ unit for $\left[{ }^{3} \mathrm{H}\right]$ PteGlu and $0.69( \pm 0 \cdot 2)$ pmol per $10 \mathrm{~min}$ per $\mathrm{OD}_{600}$ unit for $\left[{ }^{3} \mathrm{H}\right] \mathrm{MTX}$. 


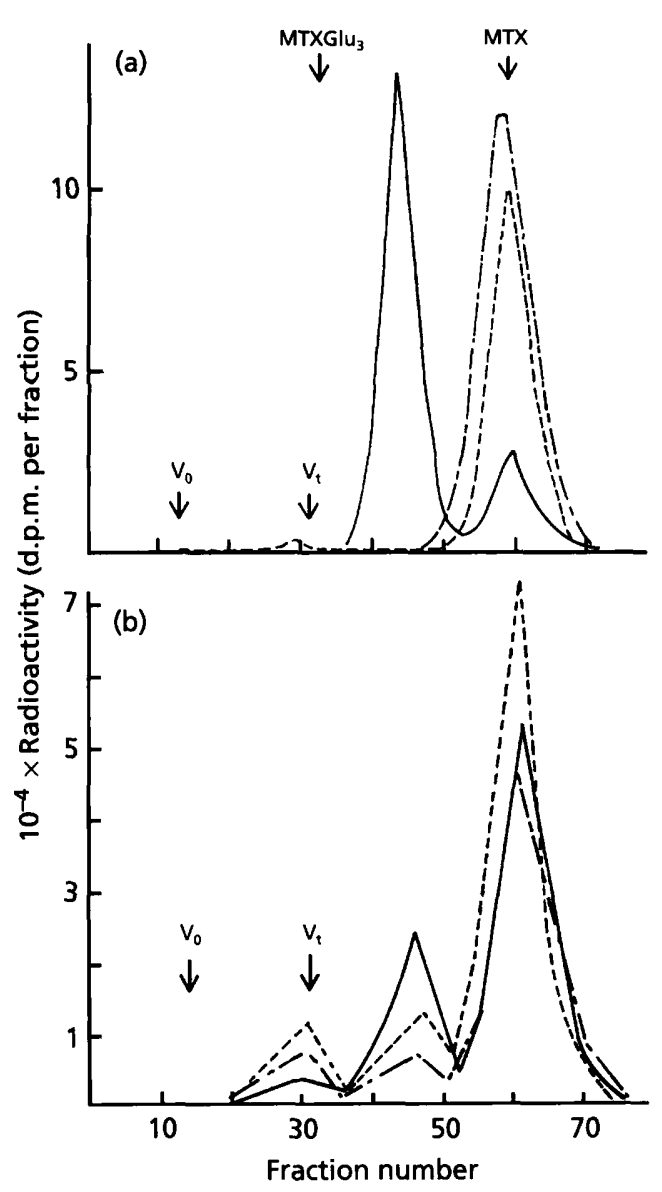

Fig. 4. Sephadex G-25 column chromatograms of intracellular (a) and extracellular (b) MTX derivatives from MTX-resistant (broken lines) and wild-type (solid lines) $E$. faecium incubated with $\left[{ }^{3} \mathrm{H}\right] \mathrm{MTX}$ for $18 \mathrm{~h}$. The void volume, $\mathrm{V}_{0}$, of the column $(1.0 \times 120 \mathrm{~cm})$ was $36 \mathrm{ml}$ and the total volume, $V_{t}$, was $94 \mathrm{ml}$. Fractions of $3 \mathrm{ml}$ were collected for measurement of radioactivity. - - -, E. faecium/MTX/5-HCO- $\mathrm{H}_{4}$ PteGlu; ---, E. faecium/MTX/PteGlu; _- E. faecium/wild. Arrows indicate the elution positions of MTXGlu and MTX.

metabolized to a polyglutamate form of MTX as a single peak, and approximately $78 \%$ of this form of MTX was retained in E. faecium/wild after $18 \mathrm{~h}$ of incubation (Table 1). In all media, the major radioactive peak in each of the three strains eluted at the position of MTX and a minor peak which corresponded to the intracellular peak found in E. faecium/wild (Fig. 4b). However, in both MTX-resistant strains radioactivity was detected only at the peak corresponding to MTX (Fig. 4a). Only 5-8\% of MTX incorporated into the cells was metabolized to polyglutamyl MTX and all were recovered in the media (Table 1, Fig. 4b).

The peak of polyglutamyl MTX in E. faecium/wild was identified as MTXGlu (MTX containing two glutamyl residues in its moiety) by treating the compound with two types of folate conjugases. As shown in Fig. 5, the elution position of the peak did not essentially change after treatment with chicken pancreas folate conjugase,

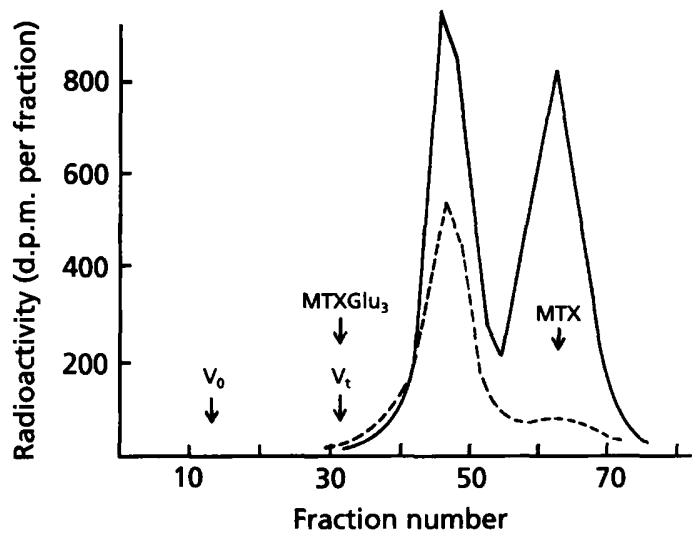

Fig. 5. Sephadex G-25 column chromatograms of MTXGlu from E. faecium/wild after treatment with chicken pancreas folate conjugase $(--)$ or human serum folate conjugase $(-)$. The void volume, $V_{0}$, of the column $(1.0 \times 120 \mathrm{~cm})$ was $36 \mathrm{ml}$ and the total volume, $V_{t}$, was $94 \mathrm{ml}$. Fractions of $3 \mathrm{ml}$ were collected for measurement of radioactivity. Arrows indicate the elution positions of MTXGlu and MTX.

which is known to hydrolyse polyglutamates to diglutamates. By contrast, there were two peaks of radioactivity at the elution positions of both MTXGlu and MTX after the original peak was treated with human serum folate conjugase, which is known to hydrolyse polyglutamates to monoglutamates (Tamura, 1990). These findings indicate that MTX was metabolized to MTXGlu in E. faecium. Furthermore, in all three strains of E. faecium, $\left[{ }^{3} \mathrm{H}\right] 4$-amino-4-deoxy-10methylpteroic acid, a degradation product of MTX having a $K_{\mathrm{av}}$ of over 4.0 as reported by Shin et al. (1974), was identified in the media (data not presented). However, there was no significant difference in the amount of radioactivity found in the peak of this degradation product among the three strains.

\section{Uptake of folates}

The uptakes of $\left[{ }^{3} \mathrm{H}\right] 5-\mathrm{HCO}-\mathrm{H}_{4}$ PteGlu and $\left[{ }^{3} \mathrm{H}\right]$ PteGlu were markedly reduced in both MTX-resistant strains as compared to E. faecium/wild. Furthermore, in E. faecium/MTX/5-HCO- $\mathrm{H}_{4}$ PteGlu, the uptakes of $\left[{ }^{3} \mathrm{H}\right] 5-\mathrm{HCO}-\mathrm{H}_{4}$ PteGlu and $\left[{ }^{3} \mathrm{H}\right] \mathrm{PteGlu}$ were approximately $54 \%$ and $63 \%$, respectively, of those in $E$. faecium/MTX/PteGlu (Table 1). The uptakes of $\left[{ }^{3} \mathrm{H}\right]$ MTX by both MTX-resistant strains were approximately $25 \%$ of that by E. faecium/wild. However, there was no difference in the uptakes of $\left[{ }^{3} \mathrm{H}\right] \mathrm{MTX}$ between the two mutant strains (Table 1).

\section{Folate-binding protein}

As shown in Fig. 6, an FBP from E. faecium/wild eluted at the void volume. This FBP showed a total $\left[{ }^{3} \mathrm{H}\right]$ PteGlu binding capacity of $6.7 \mathrm{pmol}(\mathrm{mg} \text { protein })^{-1}$. This capacity was significantly greater than those in the MTX-resistant strains $\left[0.63 \mathrm{pmol}(\mathrm{mg} \text { protein })^{-1}\right.$ for $E$. 


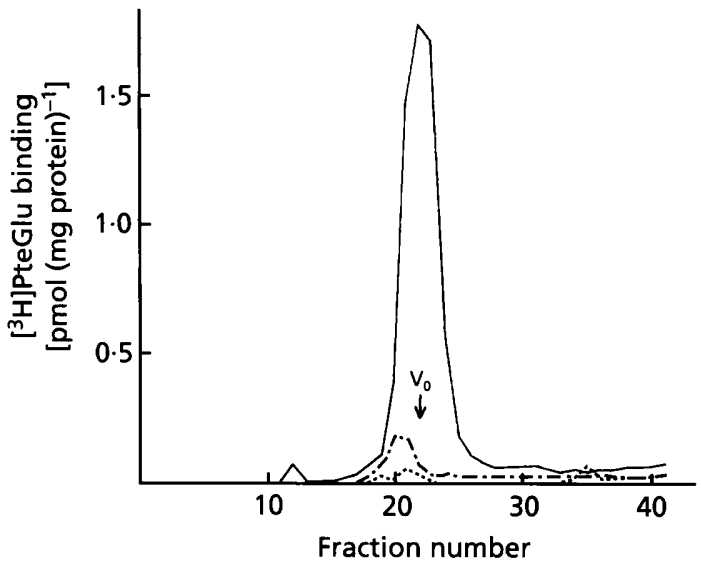

Fig. 6. Sephacryl S-200 column $(3.5 \times 30 \mathrm{~cm})$ chromatograms of FBPs obtained after solubilization of MTX-resistant (broken lines) and wild-type (solid lines) E. faecium with Triton X-100. Endogenous folate was removed from FBPs by extensive dialysis (see Methods). One hundred microlitres of this dialysed solution was incubated with an excess amount of $\left[{ }^{3} \mathrm{H}\right] \mathrm{PteGlu}$ and applied to the column. The FBP was eluted with $10 \mathrm{mM}$ phosphate buffer $(\mathrm{pH} 7.5)$ containing $1 \%(\mathrm{w} / \mathrm{v})$ Triton $\mathrm{X}-100$. Fractions of $2.75 \mathrm{ml}$ were collected for measurement of radioactivity. ---, E. faecium/MTX/5-HCO-H ${ }_{4}$ PteGlu; - - E. E. faecium/MTX/PteGlu; —, E. faecium/wild.

faecium/MTX/5-HCO- $\mathrm{H}_{4}$ PteGlu and $0 \cdot 27 \mathrm{pmol}$ (mg protein) ${ }^{-1}$ for E. faecium/MTX/PteGlu]. These data indicate that the $\mathrm{FBP}(\mathrm{s})$ level or binding affinity in MTXresistant $E$. faecium was substantially reduced when compared to E. faecium/wild.

\section{DISCUSSION}

Our data indicate that four major alterations occurred in MTX-resistant strains as compared to $E$. faecium/wild. These include: (1) increased DHFR and FAR activities in E. faecium/MTX/PteGlu; (2) decreased synthesis and intracellular retention of MTXGlu; (3) decreased uptake of MTX accompanied by decreased uptake of folates; and (4) reduced binding capacity of FBP. Among these four alterations, the activities of DHFR and FAR and the uptake of folates were markedly affected by the form of folate (either 5$\mathrm{HCO}-\mathrm{H}_{4}$ PteGlu or PteGlu) supplied in the media during the development of MTX resistance. Since the development of MTX resistance in E. faecium/MTX/5$\mathrm{HCO}-\mathrm{H}_{4}$ PteGlu required more transfers than did $E$. faecium/MTX/PteGlu, it is likely that the development of MTX resistance occurred as stepwise mutational events. This process more closely resembles naturally occurring resistance development, since 5-HCO$\mathrm{H}_{4}$ PteGlu is a natural form of the vitamin, while PteGlu is a synthetic form which does not exist in nature.

To our knowledge, there have been only a limited number of studies on the mechanisms of MTX resistance in various mammalian cell lines using a reduced form of folate as a source of folate in the medium during the development of resistance. Most studies were not designed to investigate the effect of the form of folate derivative on the mechanism of development of MTX resistance (Hakala et al., 1961; Halpern et al., 1975; van der Veer et al., 1989; Jansen et al., 1990; van der Laan et al., 1991a, b; Houghton et al., 1992; Miyachi et al., 1992).

The phenomenon observed in this study may apply only to this organism; however, the use of a reduced form of folate rather than oxidized PteGlu may be important to closely mimic physiological conditions when studying the development and mechanisms of antifolate resistance in cultured mammalian cells. For example, Miyachi et al. (1992) evaluated the effect of $5-\mathrm{HCO}-\mathrm{H}_{4}$ PteGlu or PteGlu in the media on the development of MTX resistance using K526, a human leukaemia cell line. The MTX-resistant K526 developed in the presence of PteGlu showed only impaired MTX transport as a mechanism for MTX resistance, whereas the resistant $\mathrm{K} 526$ developed in the presence of $5-\mathrm{HCO}-\mathrm{H}_{4}$ PteGlu demonstrated only increased DHFR gene expression. We previously reported that the form of folate used during the development of trimetrexate-resistant $E$. faecium affected the activities of DHFR and FAR as well as the character of FAR (Tamura et al., 1992). Thus, it is becoming clear that the form of folate likely plays an important role in the development of resistance to antifolates.

The decreased uptakes of $\left[{ }^{3} \mathrm{H}\right] 5-\mathrm{HCO}-\mathrm{H}_{4}$ PteGlu and $\left[{ }^{3} \mathrm{H}\right]$ PteGlu are consistent with the lower binding capacity of FBP to $\left[{ }^{3} \mathrm{H}\right]$ PteGlu in MTX-resistant $E$. faecium than in E. faecium/wild. The uptakes of 5$\mathrm{HCO}-\mathrm{H}_{4}$ PteGlu and PteGlu were more severely affected in $E$. faecium $/ \mathrm{MTX} / 5-\mathrm{HCO}-\mathrm{H}_{4}$ PteGlu than in $E$. faecium/MTX/PteGlu, suggesting an effect of the form of folate used in the media on the transport of folates. The decreased response of E. faecium/MTX/5-HCO$\mathrm{H}_{4}$ PteGlu to PteGlu can, in part, be explained by this finding together with the lack of increase in DHFR activity and a relatively small increase in FAR activity in this mutant strain. It should be noted that the reduction in the capacity of FBP to bind to $\left[{ }^{3} \mathrm{H}\right] \mathrm{PteGlu}$ was not necessarily parallel to the uptake of $\left[{ }^{3} \mathrm{H}\right] \mathrm{PteGlu}$ in these MTX-resistant E. faecium. It may be that the FBP identified in this study is not only functioning as a transport protein, but also playing a role that has not been identified. A correlation between decreased MTX transport and reduced FBP binding capacity suggests a causal relationship in some cells (Saikawa et al., 1993).

Our results indicate that wild-type as well as MTXresistant $E$. faecium has the capability to synthesize MTXGlu from MTX, although this capability is much lower than that in E. faecium/wild. This suggests that the activities of folylpolyglutamate synthetase are lower in MTX-resistant strains than in wild-type E. faecium as reported by Jolivet et al. (1982). Furthermore, MTXresistant E. faecium did not accumulate intracellular MTXGlu which is more toxic than MTX. MTXGlu 
leached out in the media from MTX-resistant strains indicating that these mutant strains were able to efficiently eliminate this toxic compound. The amount of radioactivity found at the position of elution of 4amino-4-deoxy-10-methylpteroic acid on Sephadex G25 chromatography was similar in all three strains suggesting a similar ability to catabolize MTX to this degradation product.

Prescott \& Affronti (1968) reported an increased folate conjugase activity in an MTX-resistant strain of $E$. faecium using yeast polyglutamates as substrate and suggested this finding as one of the mechanisms for $E$. faecium to develop MTX resistance. However, we did not find any activity of folate conjugase in MTXresistant and wild-type E. faecium using synthetic PteGlu $_{3}$ as substrate. At the present time, it remains to be determined whether the discrepancy between our results and those of Prescott \& Affronti (1968), is due to the difference in the substrates used for the assays. Nevertheless, the decreased MTXGlu levels found in MTX-resistant E. faecium could be caused by decreased synthesis of MTXGlu and/or increased degradation of MTXGlu in these resistant strains as compared to wildtype.

In summary, MTX resistance in E. faecium developed by a combination of several mechanisms including increased DHFR and FAR activities, decreased synthesis and retention of polyglutamyl MTX, decreased transport of MTX accompanied by reduced folate transport, and down-regulation of FBP. Among these, DHFR and FAR activities as well as folate transport were markedly affected by the form of folate supplied in the media during the development of MTX resistance. It may be important to use a reduced form of folate, more natural than oxidized PteGlu, in the media during the development of resistance for the study of the mechanisms of MTX resistance in cultured cells.

\section{ACKNOWLEDGEMENTS}

This study was supported in part by the Faculty Research Initiative Grant Program, School of Health-Related Professions, University of Alabama at Birmingham, and a Veterans Affairs Merit Review Award.

\section{REFERENCES}

Alt, F. W., Kellems, R. E. \& Schimke, R. T. (1976). Synthesis and degradation of folate reductase in sensitive and methotrexateresistant lines of S-180 cells. J Biol Chem 251, 3063-3074.

Antony, A. C. (1996). Folate receptors. Annu Rev Nutr 16, 501-521.

Blakley, R. L. (1969). Absorption spectra of folate derivatives. In The Biochemistry of Folic Acid and Related Pteridines, pp. 91-95. Amsterdam: North-Holland.

Blakley, R. L. (1984). Dihydrofolate reductase. In Folates and Pterins, vol. 1, Chemistry and Biochemistry of Folates, pp. 191-253. Edited by R. L. Blakley \& S. J. Benkovic. New York: Wiley.
Franklin, A. L., Belt, M., Stokstad, E. L R. \& Jukes, T. H. (1949). Biological studies with 4-amino-10-methylpteroylglutamic acid. J Biol Chem 177, 621-629.

Futterman, S. (1963). Preparation and properties of dihydrofolic acid. Methods Enzymol. 6, 801-802.

Haber, D. A., Beverley, S. M., Kiely, M. L. \& Schimke, R. T. (1981). Properties of an altered dihydrofolate reductase encoded by amplified genes in cultured mouse fibroblasts. J Biol Chem 256, 9501-9510.

Hakala, M. T., Zakrzewski, S. F. \& Nichol, C. A. (1961). Relation of folic acid reductase to amethopterin resistance in cultured mammalian cells. J Biol Chem 236, 952-958.

Halpern, R. M., Halpern, B. C., Clark, B. R., Ashe, H., Hardy, D. N., Jenkinson, P. Y., Chou, S.-C. \& Smith, R. A. (1975). New approach to antifolate treatment of certain cancers as demonstrated in tissue culture. Proc Natl Acad Sci USA 72, 4018-4022.

Houghton, P. J., Rahman, A., Will, C. L., Dolnick, B. J. \& Houghton, J. A. (1992). Mutation(s) of the thymidylate synthase gene of human adenocarcinoma cells causes a thymidylate synthasenegative phenotype that can be attenuated by exogenous folates. Cancer Res 52, 558-565.

Hutchison, D. J. (1957). Metabolism of resistant mutants of Streptococcus faecalis. I. Isolation and characterization of the mutants. Cancer Res 18, 214-219.

Jansen, G., Westerhof, G. R., Jarmuszewski, M. J. A., Kathmann, I., Rijksen, G. \& Schornagel, J. H. (1990). Methotrexate transport in variant human CCRF-CEM leukemia cells with elevated levels of the reduced folate carrier. J Biol Chem 265, 18272-18277.

Jolivet, J., Schilsky, R. L., Bailey, B. D., Drake, J. C. \& Chabner, B. A. (1982). Synthesis, retention, and biological activity of methotrexate polyglutamates in cultured human breast cancer cells. J Clin Invest 70, 351-360.

Krumdieck, C. L. \& Baugh, C. M. (1969). The solid-phase synthesis of polyglutamates of folic acid. Biochemistry 8, 1568-1572.

Krumdieck, C. L. \& Baugh, C. M. (1970). Radioactivie assay of folic acid polyglutamate conjugase (s). Anal Biochem 35, 123-129.

van der Laan, B. F. A. M., Jansen, G., Kathmann, I., Schornagel, J. H. \& Hordijk, G. J. (1991a). Mechanisms of acquired resistance to methotrexate in a human squamous carcinoma cell line of the head and neck, exposed to different treatment schedules. Eur J Cancer 27, 1274-1278.

van der Laan, B. F. A. M., Jansen, G., van Gestel, J. A., Schornagel, J. H. \& Hordijk, G. J. (1991b). Membrane transport of methotrexate in a squamous carcinoma cell line adapted to low folate concentrations. Anticancer Res 11, 1265-1268.

Leichter, J., Butterworth, C. E., Jr \& Krumdieck, C. L. (1977). Partial purification and some properties of pteroylpolyglutamate hydrolase (conjugase) from chicken pancreas. Proc Soc Exp Biol Med 154, 98-101.

Miyachi, H., Takemura, Y., Ando, Y. \& Scanlon K. J. (1992). The role of folates in the development of methotrexate resistance in human leukemia cell line K562. J Cancer Res Clin Oncol 119, 101-105.

Nixon, P. F. \& Blakley, R. L. (1968). Dihydrofolate reductase of Streptococcus faecium. II. Purification and some properties of two dihydrofolate reductases from the amethopterin-resistant mutant, Streptococcus faecium var. durans strain A. J Biol Chem 243, 4722-4731.

Prescott, L. M. \& Affronti, L. F. (1968). Presence of conjugase activity in amethopterin-resistant Streptococcus faecium. J Bacteriol 95, 2422-2423. 
Rothenberg, S. P. (1965). A radioassay for folic acid reductase. Anal Biochem 13, 530-543.

Roy, K., Mitsugi, K., Sirlin, S., Shane, B. \& Sirotnak, F. M. (1995). Different antifolate-resistant L1210 cell variants with either increased or decreased folylpolyglutamate synthetase gene expression at the level of mRNA transcription. J Biol Chem 270, 26918-26922.

Saikawa, Y., Knight, C. B., Saikawa, T., Page, S. T., Chabner, B. A. \& Elwood, P. C. (1993). Decreased expression of the human folate receptor mediates transport-defective methotrexate resistance in KB cells. J Biol Chem 268, 5293-5301.

Schweitzer, B. I., Dicker, A. P. \& Bertino, J. R. (1990). Dihydrofolate reductase as a therapeutic target. FASEB $J \mathbf{4}$, 2441-2452.

Shen, D.-W., Fojo, A., Roninson, I. B., Chin, J. E., Soffir, R., Pastan, I. \& Gottesman, M. M. (1986). Multidrug resistance of DNAmediated transformants is linked to transfer of the human $m d r 1$ gene. Mol Cell Biol 6, 4039-4044.

Shin, Y. S., Buehring, K. U. \& Stokstad, E. L. R. (1974). The mechanism of methotrexate in Lactobacillus casei and rat liver and the influence of methotrexate on metabolism of folic acid. J Biol Chem 249, 5772-5777.

Smith, P. K., Krohn, R. I., Hermanson, G. T., Mallia, A. K., Gartner, F. H., Provenzano, M. D., Fujimoto, E. K., Goeke, N. M., Olson, B. J. \& Klenk, D. C. (1985). Measurement of protein using bicinchoninic acid. Anal Biochem 150, 76-85.

Sur, P., Priest, D. G. \& Doig, M. T. (1986). Effects of growth rate and methotrexate on folate polyglutamates and folylpolyglutamate hydrolase activity in Krebs ascites cells. Biochem Cell Biol 64, 363-367.

Tamura, T. (1990). Microbiological assay of folates. In Folic Acid Metabolism in Health and Disease, pp. 121-137. Edited by M. F. Picciano, E. L. R. Stokstad \& J. F. Gregory, III. New York: Wiley-Liss.

Tamura, T., Baggott, J. E. \& Freeberg, L. E. (1992). Dihydrofolate reductase and folate reductase in trimetrexate resistant Streptococcus faecium. In Pteridines and Related Biogenic Amines and Folates, 1992, pp. 260-264. Edited by N. Blau, H. C. Curtius, R. Levine \& J. Yim. Souel: Hanrim Publishing.

van der Veer, L. J., Westerhof, G. R., Rijksen, G., Schornagel, J. H. \& Jansen, G. (1989). Cytotoxicity of methotrexate and trimetrexate and its reversal by folinic acid in human leukemic CCRF-CEM cells with carrier-mediated and receptor-mediated folate uptake. Leukemia Res 13, 981-987.

Verma, R. S. \& Antony, A. C. (1991). Kinetic analysis, isolation, and characterization of hydrophilic folate-binding proteins released from chorionic villi cultured under serum-free conditions. $J$ Biol Chem 266, 12522-12535.

Whitehead, V. M., Perrault, M. M. \& Stelcner, S. (1975). Tissuespecific synthesis of methotrexate polyglutamates in the rat. Cancer Res 35, 2985-2990.

Received 17 January 1997; revised 8 April 1997; accepted 16 April 1997. 